\title{
Adalékok Árpád-házi és Portugáliai Szent Erzsébet kora újkori ikonográfiájához: Johannes Molanus
}

\section{$I$.}

Árpád-házi és Portugáliai Szent Erzsébet két párhuzamos életpályájú királylány, akik ugyanazt a karitatív, ferences eszmeiségbőll eredeztethető női szentséget képviselik. Ez a 13. századtól megjelenő új női szentségmodell fontos szerepet biztosított az uralkodó és a nemesi családok női sarjainak. A család dicsőségét ugyanis egyre inkább a javaikról lemondó, fogadott szegénységben élő, életüket a rászorulók megsegítésének és a betegek ápolásának szentelö királynők és nemes asszonyok vitték tovább ${ }^{1}$.

Erzsébet 1207-ben született, II. András király lánya volt, aki 4 éves korától fogva a türingiai örgróf udvarában nevelkedett, majd 1221-től IV. Lajos (12171227) türingiai őrgróf felesége. Kegyes és karitatív életet élt: özvegyi járadékából kórházat építtetett Szent Ferenc tiszteltére Marburgban. Három évvel halála után szentté avatta IX. Gergely pápa. Alakját rengeteg legenda és csodás történet övezi. Legismertebb csodái: rózsacsoda, köpönyegcsoda, leprosuscsoda.

A magyar szent másodfokú unokatestvére, Portugáliai Erzsébet, akit hazájában Isabelnek vagy Szent Királynénak is hívnak, 1269-70-ben született az Ibériai félszigeten, III. Péter aragón király lányaként, akit 11 évesen adtak férjhez I. Dénes portugál királyhoz. Ö is karitatív és kegyes életet élt: újraalapította a Szent Klárának és Szent Erzsébetnek szentelt monostort, és kórházat hozott létre Szent Erzsébet tiszteletére. 1336-ban halt meg, de csak 1615-ben avatta boldoggá X. Leó pápa és 1625-ben szentté VIII. Orbán pápa. Békeszerzőként tartják számon az Ibériai-félszigeten, legismertebb csodái: rózsacsoda, a szolgáló legendája.

A két szent királylány ikonográfiája nagyban megegyezik. A fennmaradt korai ábrázolásokon a magyar királylányt gyakran koronával a fején, kancsóval, kenyérrel, betegápolás vagy adakozás közben láthatjuk. A 13. század derekán Itáliában jelenik meg először a rózsacsoda az Árpád-házi szenttel kapcsolatban. A portugál királyné esetében is gyakori, hogy jótékonykodás közben, koronával a fején ábrázolják, ezzel is utalva királyi származására és karitatív életére, emellett legtöbbször a kötényében rózsákkal reprezentálják alakját.

${ }^{1}$ KLANICZAY Gábor, Az uralkodók szentsége a középkorban, Magyar dinasztikus szentkultuszok és európai modellek, Bp., Balassi, 2000, 171. 
Árpád-házi Szent Erzsébet rózsacsodájáról így ír a Karthauzi Névtelen 1526-ban:

„Történék egy napon, mikoron nagy hideg volna, hogy úgy, mint senki ne látná, vinne apró maradékokat az vár kapuja elében az szegényeknek. És íme, elöl találá az ő atyja, csodálkozván rajta ennenmaga, mit járna és hová sietne. Megszólajtá őtet: „Fiam, Erzséböt, hova mégy, mit vissz?” Az nemes királ leánya, miért felette szemérmes vala, nagyon megszégyenlé magát és megijede, és nem tuda félelmében egyebet mit felelni: „Im, rózsát viszök.” Az ő atyja kedég mint eszös ember meggondolá, hogy nem volna rózsavirágnak ideje, hozjá hívá, és meglátá kebelét, hát mind szép rózsavirág az aszjú apró portéka. [...] Annak okáért nem akará mívelködetiben megbántani, látván, hogy mind lelki ájojtatusságában, mind jó mívelködetiben Krisztus Jézusnak ájojtatus szolgálóleánya volna."2

Portugáliai Szent Erzsébetről pedig ezt találjuk Frei Marcos de Lisboánál:

„Levava uma vez a Rainha santa moedas no regaço para dar aos pobres, encontrando-a el-Rei lhe perguntou o que levava, ela disse, levo aqui rosas. E rosas viu el-Rei não sendo tempo delas."

És ezzel szinte teljesen azonos szöveggel hozza egy spanyol legendaváltozat a portugál királynénál a rózsacsodát 1616-ban:

„Una vez llevava la Santa Reyna cierta cantidad de dineros atada a su ropa para dar a los pobres; encontrola el Rey, su marido, y preguntole que llevava, ella respondio que rosas: y mirandolas el Rey hallo que verdaderamente eran rosas, no siendo tempo de ellas."4

A rózsacsoda mindkét királylánynál fontos hagiografikus elem, a magyar és a portugál szakirodalom is saját szentjének legfontosabb jellemzőjeként tartja számon ezt a generációkon átívelő párhuzamos attribútumot.

A rózsa a szentek csodás történeteiben egy olyan topikusan ismétlődő mo-

${ }^{2}$ Karthauzi Névtelen, Dicsöséges Szent Erzsébet asszonnak innepéröl, A Néma Barát megszólal, Válogatás a Karthauzi Névtelen beszédeiből, szerk. Madas Edit, Bp., Magvető, 1985 (Magyar Hírmondó), 529. Vö. Érdy codex, II. fele, szerk. Volf György, 1876 (Nyelvemléktár, Régi magyar codexek és nyomtatványok, 5), 477.

3 A Szent Királynő egyszer pénzt vitt a kötényében, hogy azt a szegényeknek adja, mikor találkozott a királlyal az megkérdezte mit visz, ő azt mondta, hogy rózsákat viszek. És rózsákat látott a király is, pedig nem volt még ideje a virágzásuknak. (Frei MARCos de Lisboa, Cronica dos Frades Menores, 1557-1562.)

${ }^{4}$ Ribadeneyra, Pedro, Flos Sanctorum, libro de las vidas de los santos, 1616. 
tívum, mely az idők során újabb és újabb értelmezéseket, jelentéseket vett fel. ${ }^{5}$ Az étel transzformáció az éhezések korában nem volt egyedülálló csoda, a középkor szentjei elsősorban gyógyítók, táplálók voltak. Erzsébetet is nagyon sokszor ábrázolják kenyérrel és kancsóval, illetve alamizsnaosztás közben. ${ }^{6} \mathrm{Az}$ alamizsnaosztások kontextusába helyezett csoda általában büntető vagy jutalmazó szándékkal történt, a hálátlannak ehetetlenné vált az étele, vagy fordítva, a víz borrá, hús hallá változott böjtidőben. Erzsébetnél a rózsacsoda érdekessége éppen a fordítottságban rejlik, ugyanis ebben az esetben a szegényeknek szánt étel változik át valamivé, ami nem ehető. Ez természetesen azért történik, hogy kimentse Erzsébetet a kegyes hazugságból.?

\section{II.}

A rózsacsoda középkori, feltehetően itáliai eredetű jelenségét a magyar szakirodalom behatóan vizsgálta, így a dolgozat középpontjában Joannes Molanus szentek ábrázolásáról írott könyve, a De Picturis et imaginibus sacris, ${ }^{8}$ illetve ennek az 1594-ben megjelent és kibővített második kiadása, a De Historia sanctorum, Imaginum et picturarum ${ }^{9}$ áll, melyben megtalálható Árpád-házi Szent Erzsébet kora újkori ikonográfiája is.

Johannes Molanus, (Jan Vermeulen vagy Jan van der Meulen) egy 16. századi flamand teológus volt az első, ${ }^{10}$ aki a tridenti zsinat dekrétumait alapul véve könyvet írt a szentek ábrázolásáról. Az 1570-es mű előszavában három kérdésben ${ }^{11}$ foglalja össze könyve mondandóját, ezek közül az egyik a szentképek használatára vonatkozik. Munkája nagyrészt a reformáció ellen fogalmazódott meg,

${ }^{5}$ Gecser Ottó, Szent Erzsébet Rózsacsodájának elözményei és legkorábbi latin szövegváltozatai = Árpád-házi Szent Erzsébet kultusza a 13-16. században, Magyarok Nagyasszonya Ferences Rendtartomány, Bp., 2009 (Studia Franciscana Hungarica, 2), 105-122.

${ }^{6}$ Prokopp Mária, Golarits István, Árpád-házi Szent Erzsébet $=$ Tertia, 2003. Vö. Ipolyi Arnold, Magyar ikonographia, Magyarországi Szent Erzsébet képei = Egyházmüvészeti Lap, I-IV. közlemény, szerk. Czobor Béla, Bp., 1881.

7 GeCser 2009, i. m. 112-113.

${ }^{8}$ Molanus, Johannes, De Picturis et imaginibus sacris, Lovanii, Apud Hieronymum Wellaeum, 1570. https://books.google.hu/books?id=URI8AAAAcAAJ\&printsec=frontcover\&hl=hu\#$\mathrm{v}=$ onepage $\& \mathrm{q} \& \mathrm{f}=$ false $(2015$. december 2 .)

9 Molanus, Johannes, De Historia sanctorum: Imaginum et picturarum, szerk. Henricus Cuyckius, Lovanii, Apud Ioannem Bogardum, Typographum iuratum, 1594. https://books.google. hu/ books?id=jgA8AAAAcAAJ\&printsec=frontcover\&hl=hu\&source=gbs_ge_summary_r\&cad=0\#$\mathrm{v}=$ onepage \&q\&f$=$ false $(2015$. december 2 .)

10 Freedberg, David, Johannes Molanus on Provocative Paintings. De Historia Sanctarum Imaginum et Picturarum, Book II, Chapter $42=$ Journal of the Warburg and Courtauld Institutes, 1971, 229-245.

11 1. Utrum sacrarum imagninum usus legitimus sit et retinendus? 2. An liceat orare pro iis qui nunc martyres moriuntur? 3. An damnato ad mortem liceat negare eucharistiam? 
melyben hatalmas erőbedobással küzd az ekkor aktuális németalföldi képrombolók mozgalma ellen.

Az első kiadás 1570-es megjelenése után elkezdett dolgozni egy újabb, bővített kiadáson, melyet végül Henricus Cuyckius (1546-1609) adott ki a szerző halála után. A könyv nagy népszerúségnek örvendett, a 18. századig többször is újra kiadták. A De historia sanctorum imaginum et pricturarum úgy védte a katolikus képi ábrázolás helyességét, hogy közben beismerte annak időnként hibás vagy túlzó módját. Ellenezte a képeken megjelenő meztelenséget és erotikát, és nagy pontossággal határozta meg, hogy mi az, ami megengedett, hiszen kétségtelen, hogy a meztelenségnek meg volt a maga szerepe, helye és jelentősége a katolikus képi ábrázolásokon (pl.: az Utolsó ítéletnél ábrázolt emberek esetében az Isten elötti egyenlőséget jelentette). Ugyanakkor a virágkorát élö reneszánsz festészet alkotásai már nem feletek meg teljesen mértékben a tridenti zsinat elképzeléseinek.

Molanus a képeket 'idiotarum liber'-nek, ${ }^{12}$ azaz egyszerü emberek könyvének nevezte, és nagy jelentőséget tulajdonított nekik. Éppen ezért arra a következtetésre jutott, hogy nem beszüntetni kell, hanem megreformálni a képi ábrázolásokat: úgy, mint a könyvek esetében, cenzúrát kell bevezetni a festmények és szobrok esetében is. ${ }^{13}$ Éppen ezért flamand teológus emellett arra inti a müvészeket, hogy mielőtt vallási témájú képek festésébe kezdenének, végezzenek komoly kutatásokat, vizsgálják meg az autentikus forrásokat és a különböző hagiográfiákat. ${ }^{14}$ A szakirodalom szerint Molanus a legtöbb szentről az általa ismert, látott kép alapján, egyéb esetben pedig teológiai tanulmányai alapján írta le a szentek helyes reprezentációját. Írása általában véve nem tükröz egyediséget, sokkal inkább egy jól megkomponált gyüjteménye az addig felgyülemlett irodalomnak, azonban kétségtelenül érdekes színezetet ad hozzá a képek látványán nyugvó ikonográfia ismertetése. ${ }^{15}$

Következzen a Molanus kiadások vizsgálata, mely arra a kérdésre keresi a választ, hogy szerepel-e bennük, és ha igen, akkor hogyan a két női szent alakja.

Az első kiadásban (1570, Leuven) a 71. fejezetben találjuk Szent Erzsébetet, többekkel együtt: De pictura Martini Episcopi, Elizabeth viduae, et Praesentationis beatae Mariae, ahol röviden annyit írnak róla, hogy az ő attribútuma a három korona, melyek életszentségét jelképezik életének három időszakában (szüziesség, házasság és özvegység). ${ }^{16}$

A második kiadás (1594, Leuven) egy kibővített változat, ennek a címe is eltér elődjétől. Árpád-házi Szent Erzsébet e lényegesen nagyobb terjedelmű munkában a 3. könyv 48. fejezetnél található, ahol immár részletesebben írnak róla. Megtudhatjuk többek között azt is, hogy a tizenkilencedikén született királylány

${ }^{12}$ CABrol, Fernand, LeClercQ, Henri, Molanus = Dictionnaire d'archéologie chrétienne et de liturgie, tomé 11., 1934, Paris, Librairie Letouzey, 1724.

13 Uo., 1723.

14 Uo., 1725.

15 Freedberg 1971, i. m. 229.

${ }^{16}$ Elizabeth tribus coronis pingitur. Quod significat ipsam sancte vitam suam transegisse in statu virginali, maritali, et viduali. 
magyar származású, és azt is, hogy Jodocus Clichtoveus egy Erzsébet születésére írt beszédében szintén utal a három koronával történő ábrázolásra. ${ }^{17}$

A későbbi kiadásokat ${ }^{18}$ megvizsgálva arra a következtetésre juthatunk, hogy innentől kezdve ez a bővebb szövegváltozat öröklődik tovább a magyar szentröl. Az 1771-es leuveni ${ }^{19}$ kiadás annyiban tér el elődeitől, hogy Joannes Natalis Paquot francia szerkesztő, mikor újra kiadta Molanus müvét lábjegyzetekkel, pontosításokkal látta el azt, ${ }^{20}$ így - többek között - az Erzsébetről szóló rész is tovább bővül. ${ }^{21}$ Ennek a bővítésnek eredménye az is, hogy a szentek ábrázolásáról szóló munkában megjelent Portugáliai Szent Erzsébet alakja is, melynek pontos körülményei további kutatást igényelnek.

Másrészt érdemes megfigyelni azt is, hogy Árpád-házi Szent Erzsébet attribútuma az egyik korabeli ábrázolások vizsgálatán nyugvó szakirodalom szerint a három korona. A második, 1594-es kiadástól kezdve ${ }^{22}$ pedig megjelenik a Jodocus Clichtoveus (Josse Clichtove, cca. 1472-1543) prédikációra történő hivatkozás is, mely alátámasztja és meg is erősíti ezt az ikonográfiát. A flamand származású teológus Erzsébet születésére írt beszédében ${ }^{23}$ ugyanis bővebben is olvashatunk a három koronáról. Clichtoveus beszédében utal arra, hogy Árpád-házi Szent Erzsébetről olyan képek találhatóak a templomokban, ahol a három koronát egymásra helyezve tartja a kezében. ${ }^{24}$

${ }^{17}$ Die decima nona Natalem habet Elisabeth, regis Hungarorum filia, xenodochiorum et pauperum amantissima. Haec pingitur cum tribus coronis, ut significetur vitam sanctissime transegisse in statu virginali, maritali, et viduali. Quomodo hanc picturam explicat Iodocus Clichthouenus integro sermone, quem unicum edidit de Natali hujus sanctissimae Viduae. In quo pro themate assumit illud Ecclesiastici, Corona aurea super caput ejus.

18 1616. Lyon, 1619. Antwerpen, 1626. Antwerpen, 1771. Leuven.

19 Molanus, Johannes, De Historia SS: Imaginum et picturarum pro vero earum usu contra abusus, libri quatuor, szerk. Paquot, Johannes Natalis, Lovanii, Typis Academicis, 1771. https://books. google.be/books?id=dCxPAAAAcAAJ\&hl=hu\&pg=PP5\#v=onepage\&q\&f=false $(2015$. december 2.$)$

${ }^{20}$ Freedberg 1971, i. m. 230.

${ }^{21}$ Die decima nona Natalem habet Elisabeth, regis Hungarorum filia (K), xenodochiorum et pauperum amantissima. Haec pingitur cum tribus coronis, ut significetur vitam sanctissime transegisse in statu virginali, maritali, et viduali (L); quomodo hanc picturam explicat Jodocus Clichthoveus integro sermone, quem unicum edidit de Natali hujus sanctissimae Viduae; in quo themate assumit illud Ecclesiastici (23): „Corona aurea super caput ejus” (M). - (23) Cap. XLV. 14. M - (K) Mortua an. 1231., aetatis 25. - (L) Quod idem praestitit alia Elisabeth, Regina Portugalliae, defuncta IV. julii 1336. - (M) Ubi tamen legitur: „Super mitram ejus.”

${ }^{22}$ Az 1594-es kiadás előszavát megvizsgálva kiderül, hogy a kiadás előkészületeit maga Molanus végezte el, így a bővítés még írói szándékot sejttet.

${ }^{23}$ Homiliae seu sermones Iudoci Clichtovei, Coloniae, Apud Heredes Iohannis Quentely et Geruuinum Calenium, 1575, 460. https://books.google.hu/books?id=vP1NAAAAcAAJ\&lpg=PA460\&dq=corona $\% 20$ aurea $\% 20$ super $\% 20$ caput $\% 20$ eius $\&$ hl $=$ hu $\& p g=P A 460 \# v=$ onepage $\& \mathrm{q}=-$ corona $\% 20$ aurea $\% 20$ super $\% 20$ caput $\% 20$ eius\&f=true (2016. február 9.)

${ }^{24}$ Corona aurea super caput eius. Eccl. 45. cap. conscripta sunt haec verba et ibidem ducta ad literam in praeconium ipsius Aaron summi sacerdotis et fratris Mosis.

Attamen eadem nunc recte possunt applicari et accomodari in laudem S. Elisabeth viduae, cuius 
Skolasztikus aprólékossággal megmagyarázza nem csak a koronák anyagát és számát, hanem a rajtuk található ékkövek jelentőségét is, melynek ismertetésére jelen dolgozat nem vállalkozik. Az azonban ebből a beszédből is kiderül, hogy a három korona Erzsébetnél a - Molanus által is említett - három életszentséget jelképezi a szüzies ifjúságát, a tiszta házasságát, és a kegyes és szintén szüzi fogadalmat tett özvegységét.

III.

Clichtoveus alakja szorosan kapcsolódik a 16. század eleji párizsi humanizmushoz és az egyházat megújító katolikus törekvésekhez. ${ }^{25}$ Témánk szempontjából érdekesebb azonban, hogy a Sorbonne-on tanult flamand teológus neve és munkássága a magyar - Mohács előtti - müvelődéstörténet egyik fontos alakjával is összekapcsolódik.

Gosztonyi János (?-1527) tanulmányait a bécsi, ferrarai és párizsi egyetemeken végezte, és Magyarországra visszatérve hatalmas karriert futott be: eleinte a királynő udvari tolmácsa, majd hivatali tisztviselö, aki 1503-ban esztergomi kanonok, 1506-tól budai prépost, érdemeiért megkapja az 1510-es évektől a váci, majd a győri püspökséget, végül 1524-26 között királynői kancellár. Kanonokjait a bolognai egyetemre küldi peregrinálni, illetve szem elött tartja alsópapságának literátus múvelését is. Gosztonyi győri püspökként 1513-14 vagy 1514-15 között² volt kint Párizsban, ahol megismerkedett Jodocus Clichtoveusszal, akivel szoros barátságot kötött, és breviárium-, illetve misszálé-magyarázatokat kért tőle. ${ }^{27}$

Gosztonyi bőkezü mecénásként közrejátszott abban, hogy Clichtoveus megírja az Elucidatorium ecclesiasticum ad officium ecclesiae pertinentia planius exponens, et quattor libros complectens ${ }^{28}$ címü munkáját, mely elöször 1516-ban

hodie solennitatis in ecclesia celebratur: quem non unica, sicut in capite Aaron, sed triplex super caput huius beatae mulieris corona refulsit, et in aeternum fulgebit, quantum ad aeternae retributionis praemieum, quemadmodum ex praesentis sermonis deductione latius constabit.

Et id quidem expresse repraesentatur per sacram eius imaginem, pro more Christianae pietatis in ecclesijs reponi solitam quem triplicem coronam manu gestare continereque effigiatur, primam reliquis duabus subsidentem, secundam mediam, et tertiam caeteris duabus superpositam.

${ }^{25}$ EckHARdT Sándor 1929, Magyar humanisták Párizsban = Minerva, 19, 10.

${ }^{26}$ ECKHARdt 1929, i. m. 4. Vö. GÁbriel Asztrik, Gosztonyi püspök és párizsi mestere = Egyetemes Philologiai Közlöny, 1936, 15-29; Holl Béla, Jodocus Clichtoveus Elucidatoriuma és a magyarországi himnuszköltészet európai recepciója = Uö, Laus librorum, Válogatott tanulmányok, szerk. Monok István, Zvara Edina, Bp., Magyar Egyháztörténeti Enciklopédia Munkaközösség, 2000, 50. http://mek.oszk.hu/01600/01630/01630.pdf (2016. január 7.); Pannonia regia, Müvészet a Dunántúlon 1000-1541, Kiállítási katalógus, szerk. Mikó Árpád, Takács Imre, Bp., 1994, kat. sz. IX-24 (A Magyar Nemzeti Galéria kiadványai).

27 ECKHARDT 1929, i. m. 9.

${ }^{28}$ Clichtoveus, Jodocus, Elucidatorium ecclesiasticum ad officium ecclesiae pertinentia planius exponens, et quattor libros complectens, 1517. https://books.google.hu/books? id=VUrdgM7h- 
jelent meg Párizsban. Négy könyvből áll, az elsőben a zsolozsma himnuszait, a másodikban a más egyházi énekeket (antifonák, responsoriumok), a harmadikban a mise praefatiójának és kánonjának szövegeit, végül a negyedikben a misében énekelt vagy mondott prosákat, vagyis az evangélium elötti verses szövegeket magyarázza. ${ }^{29} \mathrm{~A}$ Gosztonyihoz intézett ajánlólevélben Clichtoveus nehezményezi, hogy a papság nem érzi át a szent szövegek mély jelentőségét, hanem azokat csak értelem nélkül visszamondja. A mü célja tehát, hogy a szent szövegeket közelebb hozza a papság értelméhez és szívéhez. ${ }^{30}$

Emellett feltünően sok magyar utalás található mind a himnuszokban, mind a hozzájuk füzött magyarázatokban, melyeket Clichtoveus feltehetően a megbízója által nála hagyott, nyomtatott esztergomi liturgikus könyvek felhasználásával tett bele. A szakirodalom a verses darabok szövegvariánsainak megfigyeléséből arra következtet, hogy azok forrása a Breviarium Strigoniense 1502-es vagy 1513-as kiadása, illetve a Missale Strigoniensének 1491-1513 között megjelent nyolc kiadása közül valamelyik volt, melyeket a párizsi teológus saját tetszésére másokkal is kiegészített. ${ }^{31}$

Az Elucidatorium eszme- és irodalomtörténeti fontossága abban rejlik, hogy szerepel benne hét himnusz és hat sequentia, összesen tehát tizenhárom verses szöveg, melyek a középkori Magyarországon keletkeztek, és csak magyarországi liturgikus forrásokból ismerhette őket a szerző. ${ }^{32} \mathrm{~A}$ témánk szempontjából azonban a két Szent Erzsébet-himnusz miatt kiemelendő Clichtoveus Elucidatoriuma, melyek közül az első: De Sancta Elisabeth filia regis Hungariae.

Az oktató-nevelő szándék jól érződik Clichtoveus munkáján: a himnuszokat egy-egy oldalas magyarázat követi, melyben részletesen kitér a verselés mikéntjére és a himnuszok forrásaira is. A Szent Erzsébet himnuszhoz kapcsolódó 'annontationes' részben a himnusz megrongálásán mérgelődik. Humanista müveltségéből fakadóan a lejegyezésük elött utánanézett a szövegek egyéb előfordulásainak és a jeles győri egyház használatára rendelt egyházi könyvekben ${ }^{33}$ olyan szövegvariánst talált, melyben Szent Heléna nevével helyettesítették Erzsébetét, illetve Thuringia helyett Hierosolyma szerepelt. Ezen felháborodva megjegyzi, hogy aki ezeket jóváhagyta, az nem törődött azzal, hogy így nem jön ki a szótagszám, sem pedig azzal, hogy ily módon nincsenek benne az olyan - Szent Helénának kijáró - attribútumok, mint például a Szent Kereszt felkutatása. Clichtoveus szerint ezzel próbálták hitelessé tenni az amúgy kétes értékü legendát, miszerint Szent Heléna (azaz Ilona) magyar földről származott volna,

f2IC\&printsec $=$ frontcover $\& \mathrm{hl}=\mathrm{hu} \&$ source $=\mathrm{gbs} \_\mathrm{ge} \_$summary_r $\&$ cad $=0 \# \mathrm{v}=$ onepage $\& \mathrm{q} \& \mathrm{f}=$ false (2015. december 7.)

${ }^{29}$ Holl 2000, i. m. 50. Vö. EcKhardt 1929, i. m. 9.

30 ECKhaRdT 1929, i. m. 10.

${ }^{31}$ Holl 2000, i. m. 51.

${ }^{32}$ Holl 2000, uo.

33, ,...] in libris ecclesiasticis ad usum insignis ecclesiae Jauriensis ordinatis [...]." 
amit szavahihető szerzők soha egyszer sem írtak le. ${ }^{34}$ Majd később hozzáteszi, hogy egy megbecsült fópap figyelmeztetése után megnézte a pécsi egyház használatában lévő egyházi könyveket ${ }^{35}$ is, ahol ezt a himnuszt, helyesen, Szent Erzsébetnek címezve találta meg.

Ez alapján tehát megbizonyosodhatunk afelöl, hogy Clichtoveus nem csak az esztergomi breviáriumot és missalét ismerte és használta fel az emendáláskor, hanem a győri és a pécsi egyházmegye használatában lévő könyvek is jártak a kezében, melyekkel kapcsolatban sajnos ennél pontosabban nem fogalmaz, viszont az mindenképpen kiemelendő, hogy a helyesen Szent Erzsébetnek írt himnusz kétféle változatban szerepel az említett könyvekben.

A himnuszok magyarázatánál is előkerül Erzsébet életében a hármasság - itt három lépcsőfokot (gradus) említ, és a bibliai Szent Annához hasonlítja a magyar szentet.

Azzal a Szent Annával ${ }^{36}$ osztja meg az élet hármas lépcsőfokait, akiről Lukács emlékezik meg az evangéliumban. Ezek pedig a szüzi, a házastársi, és az özvegyi. Hármas koronával magát megkülönböztetve mindenekben s ezzel a szerénységnek, türelemnek és a világ megvetésének emlékezetes példáját szolgáltatja, és jeles csodákkal fénylik, amiképpen az életének története világosan bemutatja. ${ }^{37}$

$I V$.

Árpád-házi Szent Erzsébet és Portugáliai Szent Erzsébet 15-16. századi ikonográfiájával kapcsolatban megfigyelhetö, hogy a németalföldi festők, többek között Jan van Eyck, ${ }^{38}$ Petrus Christus, ${ }^{39}$ és Jan Provost ${ }^{40}$ Árpád-házi Szent Erzsébetet há-

34, „... [ Sancta Helena ex Hungaria fuerit oriunda quod nulli unquam tradiderunt probati autores.”

35, ,...] in librum ecclesiasticum ad usum ecclesiae Quinqueecclesiensis in Pannonia [...]"

${ }^{36}$ Amikor [...] felvitték Jézust Jeruzsálembe, hogy bemutassák az Úrnak, Volt ott egy prófétanő is, Anna, Fánuel leánya, Ásér törzséből. Nagyon előrehaladott korú volt; csak hét évig élt férjével hajadonkora után, és már nyolcvannégy éve özvegyasszony volt. Nem távozott el a templomból, mert böjtöléssel és imádkozással szolgált éjjel és nappal. (Lk 2,36)

37 „Triplicem autem cum sancta illa Anna, cuius meminit Lucas in evangelio, sortita vitae gradum per diversa temporum curricula, virginalem, coniugalem et vidualem, triplicique insignita corona in omnibus se humilitatis, patientiae, paupertatis et comtemptus mundi memorabile praebuit exemplum et insignibus claruit miraculis, quemadmodum historia vitae eius omnibus ad manum prompta dilucide monstrat."

${ }^{38}$ Eyck van, Jan, Szüz Mária Szentekkel és Patrónussal, 1441, The Frick Collection, New York, USA, http://www.wikiart.org/en/jan-van-eyck/virgin-and-child-with-saints-and-donor-1441\#close (2016. május 18.) - L. 1. melléklet.

${ }^{39}$ Christus, Petrus Portugál Izabella és Árpád-házi Szent Erzsébet, 1457-60, http://www.wga. hu/html/c/christus/2/isabel.html (2015. november 18.) - L. 3. melléklet.

${ }^{40}$ Provost, Jan, Árpád-házi Szent Erzsébet, Palazzo Doria Brignole, Musei di Strada Nuova, https://commons.wikimedia.org/wiki/File:Santa_Elisabetta_d\%27Ungheria_di_Jan_Provoost.JPG (2016. május 18.) - L. 2. melléklet. 
rom koronával festik meg. A magyar szent Petrus Christusnak egy másik képén ${ }^{41}$ is három koronával szerepel. Igaz, itt a falra kitüzött nyomtatott szentkép formájában. ${ }^{42}$ Így azonban a festmény az első nyomtatott magyar vonatkozású nyomtatvány létét dokumentálja még akkor is, ha a metszetből nem ismert példány. ${ }^{43}$

Ugyanakkor a fél évszázaddal később megjelenő ábrázolásokon Portugáliai Szent Erzsébetet a számunkra is ismerős rózsacsoda motívumával ábrázolják.

I. Manuel király fia Ferdinánd infáns rendelte meg azt az 1530-34 között készült portugál királyi családot ábrázoló genealógiai táblát, ${ }^{44}$ melyet a németalföldi miniaturista, Simon Bening (1483-1561) készített el Antonio de Holanda rajzai alapján. ${ }^{45}$ Ez utóbbi életéről keveset tudunk, azonban neve alapján szintén feltételezhető a németalföldi kötődés. Ök úgy ábrázolják a portugál szentet, hogy rózsákat tart a kötényében. ${ }^{46} \mathrm{Az}$ oldal széleit díszítő kisebb rajzok pedig egyéb életrajzi részleteket jelenítenek meg, az egyik azt ábrázolja, amikor az özvegy királyné férje halála után elzarándokolt Santiago de Compostelába. A genealógiai tábla magyar müvelődéstörténeti szempontból is figyelemre méltó adatokat tartalmaz, ${ }^{47}$ ugyanis megjelennek lapjain a magyar uralkodóház tagjai is. Ennek az az oka, hogy a 16. században a portugál történetírás a saját uralkodói családját magyar felmenőkig - ezen a genealógiai táblán egészen Géza fejedelemig - vezette vissza. Ez a köztudatban lévő, ám kevés történelmi alappal rendelkező legenda munkálhatott Luis de Camõesben is, amikor a Lusiadák című híres eposzában így ír Portugália első királyáról:48 „Közöttük Henrik (egy magyar királynak/ volt a második derék fia, mondják)/Portugáliát kapta [...]." 49

${ }^{41}$ Christus, Petrus, Patrónus felesége, 1450 k. National Gallery of Art Washington, http:// www.wga.hu/html/c/christus/1/donator2.html (2016. május 27.) - L. 13. melléklet.

${ }^{42}$ Die Anfänge der europäischen Druckgraphik. Holzschnitte der 15. Jahrhundert und ihr Gebrauch, Hrsg. von Peter Parshall, Rainer Schoch, mit David S. Areford, Richard S. Field, Peter Schmidt (Ausstellungskatalog), National Gallery of Art, Washington, 4. September - 27. November 2005; Germanisches Nationalmuseum, Nürnberg, 15. Dezember 2005. - 19. März 2006. Nürnberg, Germanisches Nationalmuseum, 2005, 41-43.

${ }^{43}$ MonoK István, Die Anfänge der europäischen Druckgraphik, Holzschnitte der 15. Jahrhundert und ihr Gebrauch (Ausstellungskatalog), Nürnberg, 2005, 291-294. - L. 14. melléklet.

${ }^{44}$ Bening, Simon, Hollanda, Antonio de, Leaves from the Genealogy of the Royal Houses of Spain and Portugal (the ,Portuguese Genealogy'), 1534-1530, British Library, MS 12531, http:// www.bl.uk/manuscripts/FullDisplay.aspx?ref=Add_MS_12531 (2016. február 10.) - L. 4. melléklet.

45 Pimentel, António Filipe, A representação gravada da Rainha Santa Isabel: política e devoção $=$ Cultura, 2010, 84. https://cultura.revues.org/358 (2016. május 3.).

${ }^{46}$ Holanda - Bening 1534-1530, i. m. f.9*r http://www.bl.uk/manuscripts/Viewer.aspx?ref=add_ms_12531_f001r (2016. február 10.)

${ }^{47}$ Bán Péter, Szent István kultusza Portugáliában = História, 1988, 4.

48 LAdÁNYI-Túróczy Csilla, Legendás magyarság-kép a 16. századi portugál irodalomban = Palimpszeszt, 2001. július. http://magyar-irodalom.elte.hu/palimpszeszt/15_szam/04.htm (2016. május 08.)

49 CAmões Luis de, A Lusiadák, III. ének 25., 1-3, ford. Hárs Ernő, Bp., Mundus Magyar Egyetemi Kiadó, 1997. 
Egy másik 16. század közepén készült táblakép, ${ }^{50}$ mely a coimbrai Machado de Castro Múzeumban található, szintén rózsákkal a kötényében ábrázolja Portugáliai Szent Erzsébetet. A kép kapcsolatba hozható Martim Azpilcuetával, a Doctor Navarrusként is emlegetett baszk egyházjogász és teológus ugyanis feltehetőleg saját megrendelésére készíttetette el. ${ }^{51}$ És úgy tünik, hogy a rózsacsodával történő ábrázolás hagyományát - ha nem is kizárólagosan, de - követik a későbbi spanyol és portugál festők is, például Francisco de Zurbarán. ${ }^{52}$

$V$

A Molanusnál és Clichtoveusnál is leírt Szent Erzsébet ábrázolásokat - ahol három korona volt az attribútuma - a németalföldi festők ábrázolási gyakorlatában is nyomon lehetett követni. Felmerül a kérdés, hogy vajon ennek a gyakorlatnak volt-e nyoma a korabeli Magyarországon?

I. László szentté avatása után (1192) kezdetét veszi a magyar szent királyok kultusza, ${ }^{53}$ az ún. Sancti Reges Hungariae: Szent István, Szent Imre, Szent László hármasa. Ez később Árpád-házi Szent Erzsébettel és a szentként tisztelt Boldog Margittal $^{54}$ egészül ki.

A 15. század második felétől tovább bővült a magyar szentek sora, annak köszönhetően, hogy a század végére átalakult annak megítélése, hogy ki számít magyarnak a szentek közül. Ugyanis nemcsak azok, akik Magyarország területén születtek, hanem azok is, akik itt tevékenykedtek (pl. Szent Gellért, vagy az itt remetéskedő Benedek és Zoerard - Szórárd), ${ }^{55}$ egyes szentek pedig liturgiatörténeti szempontból váltak magyarokká (pl. amikor Alamizsnás Szent Jánosnak Magyarországra kerültek a maradványai).

A magyar szent királyok és a velük fogalmilag összekapcsolódó magyar szentek kultusza folyamatosan terjedt külföldön is az aacheni, kölni, mariazelli, loretói és római búcsújárásokkal, a liturgikus müvek terjedésével, és az uralkodói követjárások, illetve diplomáciai kapcsolatok révén is. Mindez a török fenyegetés miatt újabb lendületet kapott: a Propugnaculum Christi gondolatkörébe jól illeszkedett a magyar szent királyok tisztelete, hiszen az ország és Európa védelmét várták tőlük.

${ }^{50}$ Ismeretlen festő, Portugáliai Szent Erzsébet királyné, 1538-55 között, Machado de Castro Nemzeti Múzeum, Coimbra, MNMC 11268. http://www.museumachadocastro.pt/pt-PT/coleccoes/ Pintura/ContentDetail.aspx?id=201 (2016. május 18.) - L. 5. melléklet.

51 Pimentel 2010, i. m.

${ }^{52}$ Zurbaran, Francisco de, Portugáliai Szent Erzsébet, 1638-42. http://www.wga.hu/html/z/ zurbaran/2/casilda.html (2016. május 18.) - L. 6. melléklet.

${ }^{53}$ KeRny Terézia, Magyar szentek tisztelete és képzömüvészeti ábrázolásai (13-18. század) = Magyar Müvelödéstörténeti Lexikon, Középkor és kora újkor, 7, szerk. Kőszeghy Péter, Bp., Balassi, 2014, 216-243.

54 1276-ban avatták boldoggá, 1943-ban szentté.

${ }_{55}$ Uo. Vö. PražÁk, Richard, A Legenda sanctorum Zoerardi et Benedicti történelmi és kulturális összefüggései = Irodalomtörténeti Közlemények, 1980, 393-408. 
Emellett a humanizmus szövegkritikai hagyománya mentén tudományos igényü feltáró munka kezdődött a szentek életére vonatkozóan (is): a jezsuita rend az Acta Sanctorumba gyüjtötte össze a valaha volt összes szentet, hozzájuk kapcsolódó legendákat $\mathrm{s}$ azok hiteles történelmi hátterét. Jean Bolland nagyszabású vállalkozása rendelkezik dogmatikai felekezeti éllel is, ugyanis a protestánsok nemcsak a szentek legitimitását, hanem a rájuk vonatkozó történeti hagyományt is kétségbe vonták. Nem véletlen, hogy Magyarországon is főleg a jezsuitákhoz köthetőek az első ilyen jellegü összefoglaló munkák. A továbbiakban a teljesség igénye nélkül szeretnék kiemelni ezek közül néhányat.

Inchofer Menyhért ${ }^{56}$ (1584-1648) lutheránus nemesi családból származott, de 1607-ben Rómában noviciusnak jelentkezett a jezsuitákhoz. Tanulmányai végeztével Itáliában maradt, és matematika-, filozófia- és teológiatanárként müködött. Jakusics György, veszprémi püspök bíztatására hozzákezdett egy nagyszabású magyar egyháztörténeti munka összeállításához. 1644-ben elkészült az Annales eclesiastici regni Hungariae ${ }^{57} 1059$-ig terjedő első kötete. Vállalkozása egybeesett a bollandistákéval, hiszen az Acta Sanctorum első kötete 1643-ban jelent meg. Inchofer Menyhért munkájának címlapján, ahol megjelennek a magyar szentek - többek között Szent István, Szent Imre, Szent László és Szent Erzsébet is. Erzsébetet a jobb alsó sarokban, fején koronával ábrázolják, mely a királyi származásra utal, egyik kezében könyvet tart, másikkal adományt nyújt. Sem a rózsák, sem a hármas korona nem jelennek még meg.

A vele nagyjából egy időben Magyarországon tevékenykedő Pázmány Péter ${ }^{58}$ (1570-1637) erőteljesen szorgalmazta a magyar szentek felvételét a tridenti zsinat (1545- b1563) szellemében készült liturgikus szerkönyvekbe, amit 1631-ben sikerült is elérnie. Pázmány mint a katolikus arisztokrácia tagja támogatta a magyar szent királyok kultuszát, e mögött pedig a katolikus dogmatikán túlmutató, a Habsburgoktól függetlenedni vágyó állam víziója volt. Ez lehet az oka annak, hogy a 17. század közepétől megnő a saját - magyar - szentek és hősök propagálása. Ennek megfelelően Pázmány 1613-ban megjelent Isteni igazságra vezérlö kalauz címü munkájának díszcímlapján ${ }^{59}$ a négy magyar szent (István, Imre, László és Erzsébet), felettük pedig a Patrona Hungariae alakja látható ${ }^{60}$. Erzsébetet itt három

${ }^{56}$ KuLcsÁR Péter, Inchofer Menyhért = Magyar Müvelödéstörténeti Lexikon, Középkor és kora újkor, 4, szerk. Kőszeghy Péter, Bp., Balassi, 2014, 286-289.

${ }^{57}$ InCHOFER Melchior, Annales ecclesiastici regni Hungariae, tomus primus, typis Ludouici Grignani, 1644.https://books.google.hu/books?id=WYpMAAAAcAAJ\&dq=inchofer\%20melchior $\% 20$ annales $\% 20$ ecclesiastici $\& \mathrm{hl}=\mathrm{hu} \& \mathrm{pg}=\mathrm{PP} 13 \# \mathrm{v}=$ onepage \&q\&f=false (2016. május 18.) - L. 5. melléklet.

58 KeRnY 2014, i. m. 220.

59 PÁzmány Péter, Isteni igazságra vezérlő kalauz, 1613. http://deba.unideb.hu/deba/emlekezethely/ dok.php?id=15 (2016. február 20.) - L. 7. melléklet.

${ }^{60}$ Lásd Bitskey István, Szent Erzsébet a kora újkori magyar irodalomban = Debreceni Szemle, 2008, 214-222. 
koronával ábrázolják úgy, ahogy ezt Molanusnál is olvashattuk. További vizsgálatot igényel, de mindenesetre elgondolkodtató, hogy a Nagyszombati Egyetem könyvtárának 1632-es katalógusában szerepel az 1594-es Molanus-kiadás. ${ }^{61}$

Nádasdy Ferenc ${ }^{62}$ (1623-1671) evangélikus környezetben nevelkedett, de itáliai peregrinációja után 1644-ben katolizált, és a rákövetkező évben már jezsuita missziót hozott létre a hit terjesztésére. Politikus és mecénás, aki köztudottan támogatta a múvészeteket is. Számos templomot és búcsújáróhelyet is patronált, ezek közül az 1662-ben Szent István tiszteletére alapított kápolnát fontos kiemelni, mely a mariazelli kegytemplom első magyar alapítású kápolnája. ${ }^{63}$ Itt található az a Tobias Pock által festett barokk oltárkép, melyet feltehetőleg Nádasdy intenciói alapján készített, és amely az egyik első ábrázolása a Regnum Marianum-témának: Szent István térdelve nyújtja az országot jelképező koronát Máriának. Témánk szempontjából azért kiemelendő ez a kápolna, mert a mennyezetfreskók ${ }^{64}$ között Szent Ferenc stigmatizációja mellett négy magyar szent alakja látható: Szent István és Szent László, Szent Erzsébet, és - Galavics Géza megállapítása szerint - Portugáliai Szent Erzsébet. ${ }^{65}$ Más vélemények szerint a negyedik freskó Árpád-házi Margitot ${ }^{66}$ ábrázolja. A két nőalak közül az egyik szerzetesi ruhát visel, fején korona, kezében további két koronát tart egy könyvön. ${ }^{67} \mathrm{~A}$ másik nőalakot díszes, világi ruhában ábrázolták. ${ }^{68} \mathrm{~A}$ molanusi hagyomány alapján Árpád-házi Szent Erzsébet attribútuma a három korona, így ő az, akit szerzetesi ruhában festettek meg. A másik alak viszont nem lehet azonos Árpád-házi Margittal, aki ugyan királyi származású volt, de egész életét kolostorban töltötte, ellentétben a portugál és a magyar Erzsébettel, akik csak özvegységükben vonultak vissza a világi élettől - Margitot ezért nem ábrázolták volna világi öltözékben. Ellene szól az is, hogy alakját ugyan nagy tisztelet övezte Magyarországon, de szentté avatását a 20. századig nem sikerült kieszközölni Rómában.

Így tehát a másik női alakban, Galavics alapján, Portugáliai Szent Erzsébetet látjuk, aki 1644-ben magyar szentként jelenik meg a kápolna ferences tematikájú mennyezetfreskóján, s akinek magyar szentként való felemlítése korántsem kivételes jelenség a 17. században. Jól szemléltetik ezt a 17. század végén, 18. század elején népszerüvé vált enciklopédikus jelleggel megszerkesztett szentek élete kiadványok.

${ }^{61}$ Farkas Gábor Farkas, A Nagyszombati Egyetemi Könyvtár az alapitáskor, Bibliotheca Antiquissima (1586-1635) = A Kárpád-medence koraújkori könyvtárai, III, szerk. Monok István, 186.

${ }^{62}$ Viskolcz Noémi, Nádasdy (III.) Ferenc, gr. = Magyar Müvelödéstörténeti Lexikon, Középkor és kora újkor, 8, szerk. Köszeghy Péter, Bp., Balassi, 2014, 64-70.

${ }^{63}$ Galavics Géza, Magyar föurak és a Mariazelli bazilika magyar kápolnái = Mariazell és Magyarország, Egy zarándokhely emlékezete, kiad. Farbaky Péter, Serfőző Szabolcs, Bp., Budapesti Történeti Múzeum Kiscelli Múzeum, 2004, 93-112. - L. 8-10. mellékletek.

${ }^{64}$ Galavics 2004, i. m. 103. - L. 8. melléklet.

${ }^{65}$ Galavics 2004, i. m. Vö. Viskolcz 2014, i. m. 67.

${ }^{66}$ Udvarhelyi Olivér, Magyar Emlékek Máriacellben. http://www.jelujsag.hu/magyar-emlekek -mariacellben (2016. május 11.)

${ }^{67}$ L. 9. melléklet.

${ }^{68}$ L. 10. melléklet. 
Illyés András ${ }^{69}$ (1637-1712) a magyar barokk egyházi irodalom sokoldalú és termékeny képviselője volt. Nagyszombatban majd Rómában tanult, bölcsészdoktori fokozatot szerzett, később erdélyi püspök lett. Összeállította a szentek életrajzát $A$ keresztyéni életnek példája avagy tüköre ${ }^{70}$ címmel magyar nyelven, amely 1682-83-ban jelent meg Nagyszombatban. Számos kiadást ért meg, 1694ben latinul is megjelent. A bollandisták előfutárának tartották. A föként olasz forrásokból építkező művében mind Árpád-házi Erzsébet, mind Portugáliai Erzsébet szerepelnek, hiszen ekkorra már Portugáliai Erzsébet is kanonizált szent (1625). Érdekes módon az Árpád-házi szentnél nyoma sincs a rózsacsodának, helyette Portugáliai Szent Erzsébet alatt közli a következőket: „A szegényeknek pénzt osztogatván, hogy a királynál titkon lenne, téli időben rózsákká változtatta."

Hevenesi Gábor ${ }^{71}$ (1656-1715) jezsuita egyháztörténész volt, a teológia és a filozófia doktora, aki a nagyszombati egyetemen tanított. Magyar szentekről szóló munkája latinul is, magyarul is megjelent Ungariae sanctitatis indicia / Régi magyar szentség, Nagyszombat, 1692/1695..$^{72}$ A könyv a magyar múlt megismerését szorgalmazta: Szent Istvántól kezdve összegyújtötte a magyarnak számító szentek és boldogok rövid életrajzát, melyet egy-egy rézkarccal egészített ki. Az addig megjelent legteljesebb életrajz- és ábrázolásgyüjtemény volt ez, mely irodalmi és képzőművészeti mintaként évszázadokra meghatározta egy-egy szent ikonográfiáját. Ebben is Portugáliai Szent Erzsébetnél találjuk a rózsacsodát ezzel a szöveggel: „Amidőn egyszer elindult, hogy pénzt osszon szét közöttük, véletlenül szembejött vele királyi férje. Hogy rejtve maradjon elötte az alamizsna, télvíz idején rózsává változtatta a pénzt." $\mathrm{S}$ ennek megfelelően a hozzá tartozó képen egy virágszál látható a tenyerén. Árpád-házi Szent Erzsébetet pedig három koronával ábrázolja az életrajz melletti metszeten. ${ }^{73}$

Csete István ${ }^{74}$ (1648-1718) Vágsellyén született, 19 éves korában lépett a rendbe, Trencsénben és Bécsben tanult, 1675-től a poézis tanítója volt Kassán, majd misszionárius lett Erdélyben, ahol nem nézték jó szemmel a jezsuitákat, ezért álnéven, álruhásan, álúton érkezett Gyulafehérvárra. Következő állomása Ko-

${ }^{69}$ MACZÁK Ibolya, Illyés András = Magyar Müvelödéstörténeti Lexikon, Középkor és kora újkor, 4, szerk. Köszeghy Péter, Bp., Balassi, 2014, 281-282.

${ }^{70}$ ILLYÉs András, Keresztyéni életnek példája avagy tüköre, azaz a szentek élete, 1683. https:// books.google.hu/books?id=wVFdAAAAcAAJ\&printsec=frontcover\&hl=hu\&source=gbs_ge_ summary_r\&cad $=0 \# \mathrm{v}=$ onepage \&q\&f=false (2016. május 17.)

${ }^{71}$ BÁNKI Éva, Hevenesi Gábor = Magyar Müvelödéstörténeti Lexikon, Középkor és kora újkor, 4, szerk. Kőszeghy Péter, Bp., Balassi, 2014, 120-121.

72 [Hevenesi Gabriel], Ungariae sanctitatis indicia, Nagyszombat, 1737. https://books.google. hu/books?id=PR8VAAAAQAAJ\&lpg=PA45\&ots=--0E-g-waZ\&dq=ungariae $\% 20$ sanctitatis $\% 20$ indicia\&hl=hu\&pg=PT18\#v=onepage \&q=elizabeth\&f=false (2016. május 17.)

${ }^{73}$ Hoffman, Schott, Régi Magyar Szentség (metszetek). http://www.ppek.hu/k60.htm (2016. március 13.) - L. 11-12. mellékletek.

${ }^{74}$ Kiss Anna, Csete István = Magyar Müvelödéstörténeti Lexikon, Középkor és kora újkor, 2, szerk. Kőszeghy Péter, Bp., Balassi, 2014, 135. Vö. GÁBor Csilla, Női szentség, nemzeti szentség, Szent Erzsébet-prédikációk a 17-18. század fordulóján = Debreceni Szemle, 2008, 204-213. 
lozsvár, ahol tizenkilenc évet töltött, majd Nagyszombat, Győr, itt már helyettes tartományfőnök; végül Sopronban halt meg.

Panegirici Sanctorum Patronorum Regni Hungariae, tudniillik Nagyasszonyról, magyar szentekröl és az országhoz tartozandó kiváltképpen való innepekre jeles predikációk, ${ }^{75}$ 1754-ben Kassán megjelent munkáit rendtársa Gyalogi János fordította magyarra és adta ki, Csete halála után. Prédikációiban mindkét szent szerepel mint rokonok, Árpád-házi Szent Erzsébetet hármas koronájáról tartja híresnek, Portugáliai Szent Erzsébet csodái közül kiemeli a gyógyító csók csodáját és a rózsacsodát.

Az idézett 17. századi szerzők alapján meglepő módon az látszik, hogy a rózsacsoda motívumát Portugáliai Szent Erzsébetnél közlik, a magyar szentnél pedig inkább a karitatív életmódot hangsúlyozzák.

\section{Mellékletek}

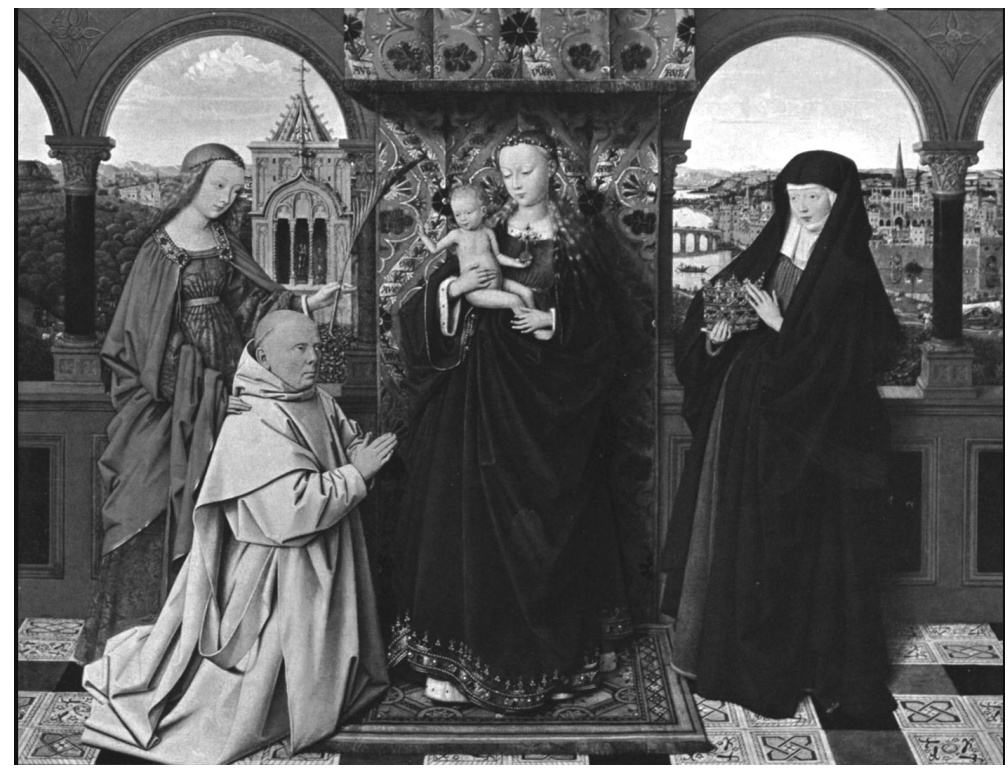

1. melléklet.

Jan van Eyck: Szüz Mária gyermekével, Szentekkel és Patrónussal, 1441

${ }^{75}$ Csete István, Panegyrici sanctorum patronorum Regni Hungarice, Tudni-illik, Nagy-Aszszonyról, Magyar Szentekröl, és az Országhoz tartozandó kivált-képpen-való innepekre jeles prédikatziók, szerk. Gyalogi János, 1754. https://books.google.cz/books?id=f6xXAAAAcAAJ\&hl=hu\&pg=$\mathrm{PA} 255 \# \mathrm{v}=$ onepage $\& \mathrm{q} \& \mathrm{f}=$ false (2016. április 14.) 


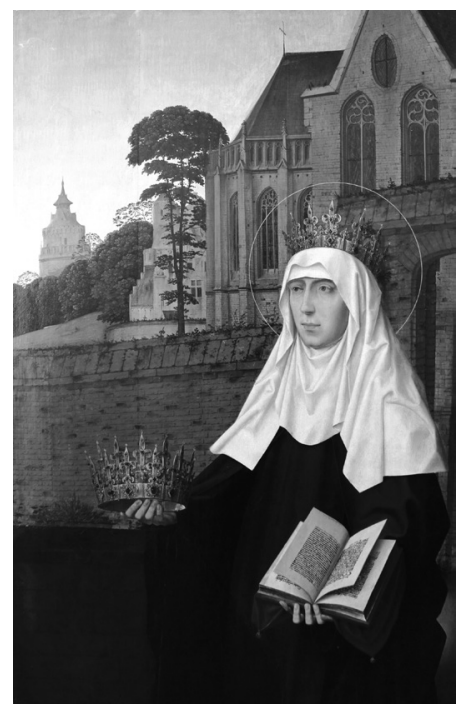

2. melléklet.

Jan Provost (1565-1529):

Árpád-házi Szent Erzsébet

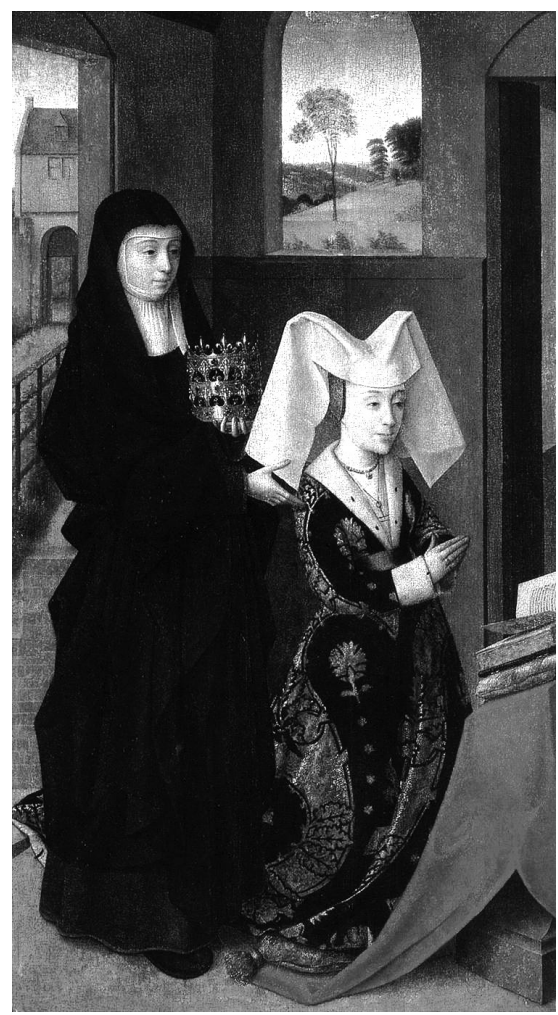

Petrus Christus: Portugál Izabella Árpád-házi Szent Erzsébettel, 1457-60

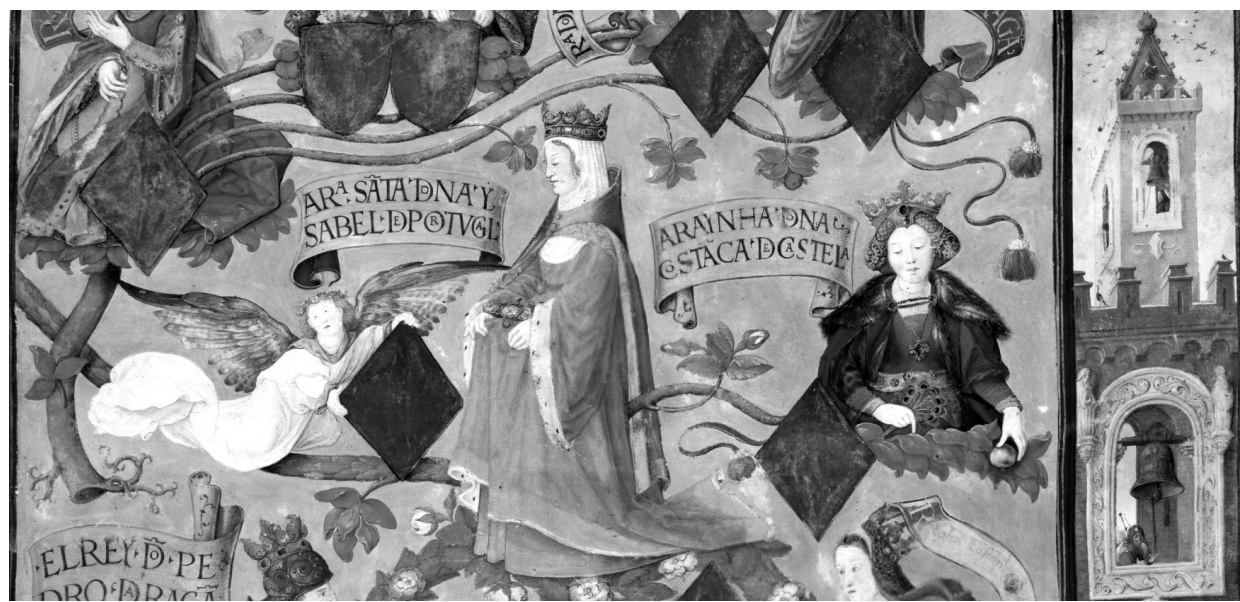

4. melléklet.

Antonio de Holanda: Portugál királyi családfa, 1530-34 


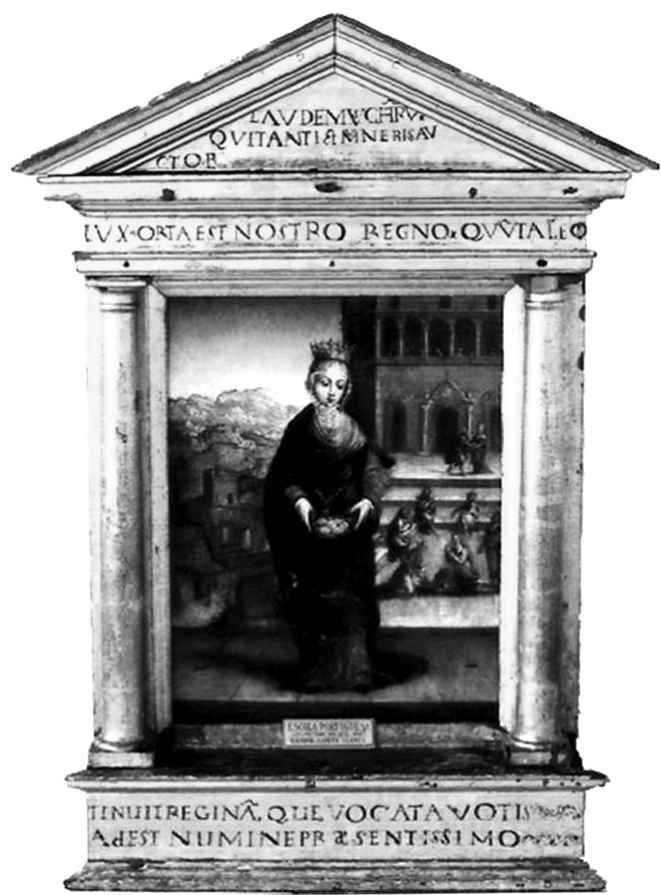

5. melléklet.

Ismeretlen festö:

Portugáliai Szent Erzsébet, 1538-55

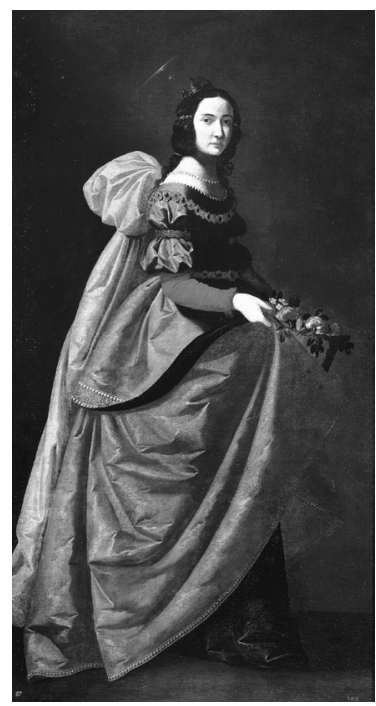

6. melléklet.

Francisco de Zurbaran, 1635

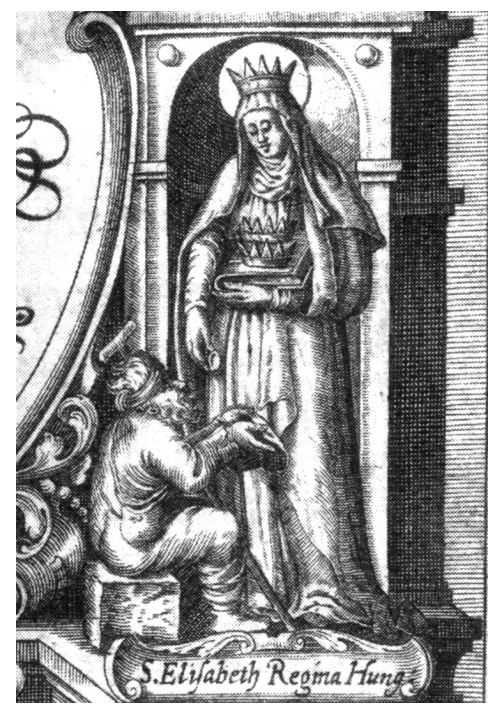

7. melléklet.

Pázmány Péter: Isteni igazságra vezérlö kalauz (címlap részlet), 1613 
8. melléklet.

Szent István kápolna boltozata

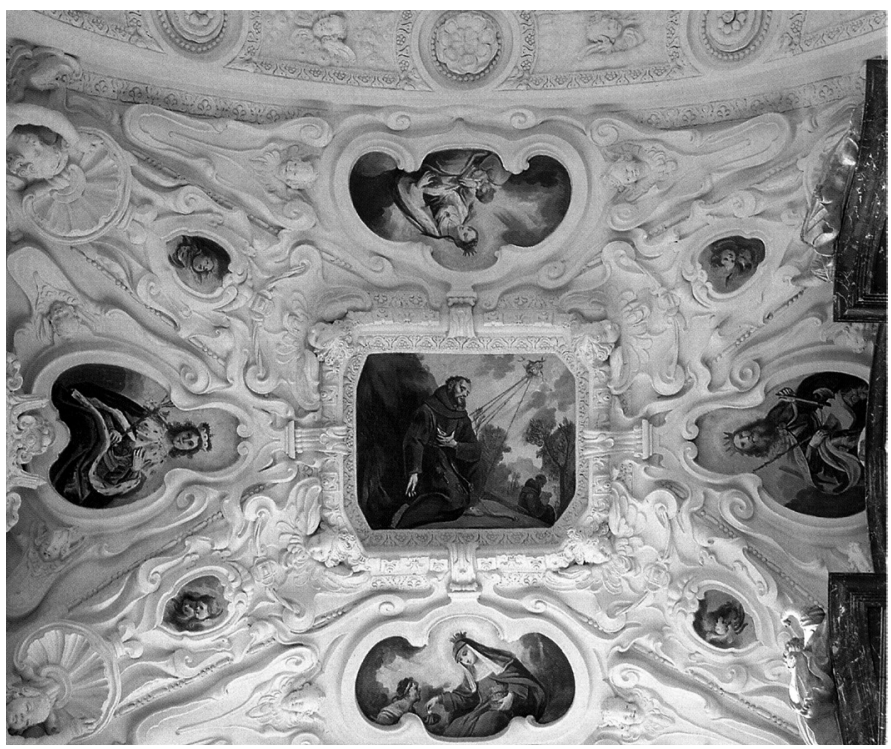

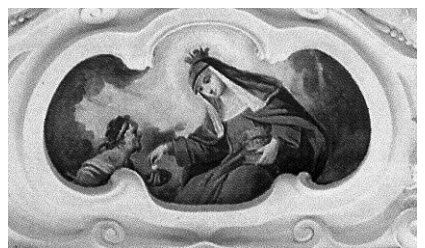

9. melléklet.

Árpád-házi Szent Erzsébet

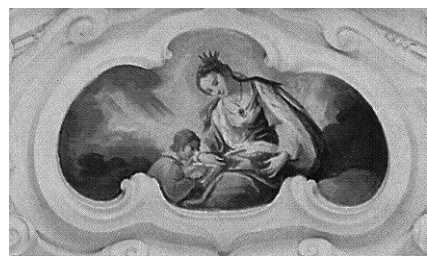

10. melléklet.

Portugáliai Szent Erzsébet

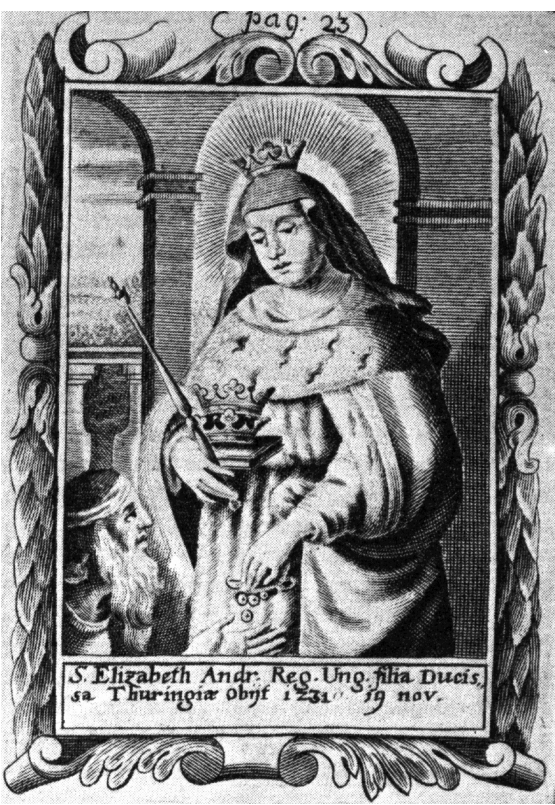

11. melléklet.

Schott Hoffman: Árpád-házi Szent Erzsébet, 1689, (Régi Magyar Szentség, metszetek) 


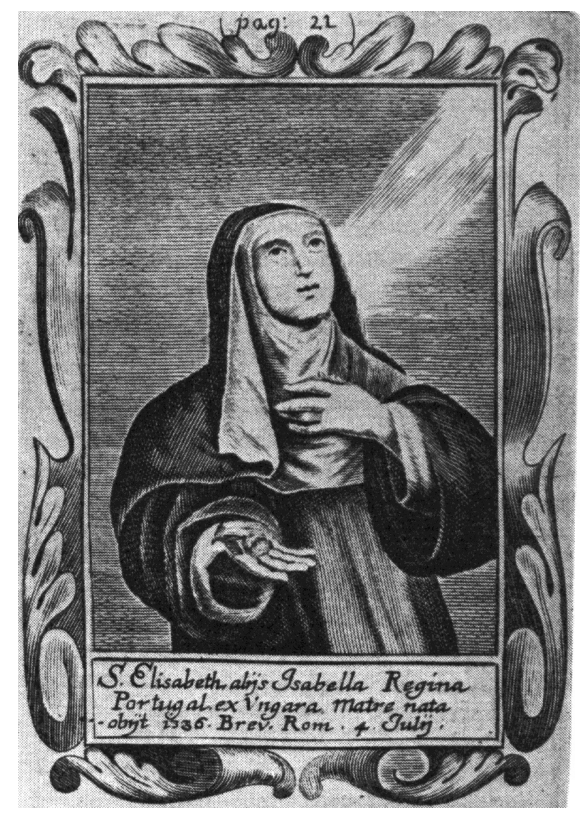

12. melléklet.

Schott Hoffman: Portugáliai Szent Erzsébet 1689, (Régi Magyar Szentség, metszetek)

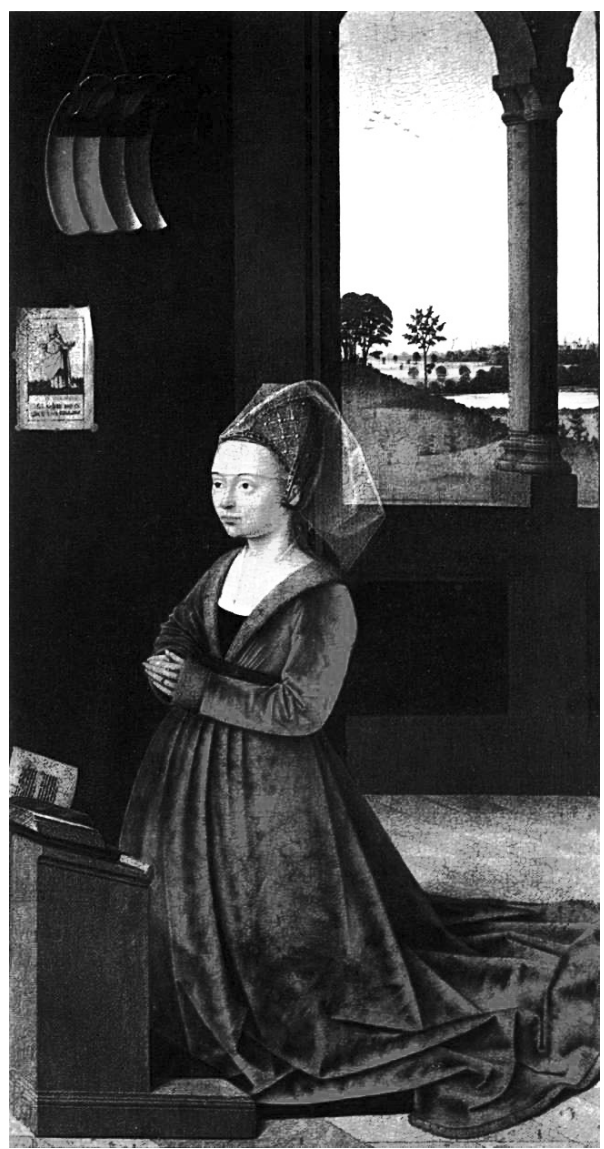

13. melléklet.

Petrus Christus: Patrónus felesége, 1455 körül
14. melléklet.

Metszet - a festmény hátterében - Árpád-házi Szent Erzsébetröl 


\title{
SZÜCS, KATA ÁGNES
}

\section{Aditivos ao iconografia da Santa Isabel de Hungria no inicio da Idade Moderna: Johannes Molanus}

\author{
[Additions to the early modern iconography of Saint Elizabeth of \\ Hungary and of Portugal: Johannes Molanus]
}

O desenvolvimento do culto e da iconografia de Santa Isabel da Hungria e de Santa Isabel de Portugal e a correlação entre eles é um processo complexo e contínuo ao longo da história.

Este artigo descreve a formação da iconografia de Santa Isabel da Hungria e da Santa Isabel de Portugal no início da era moderna, baseada no livro de Johannes Molanus De historia sanctorum imaginum et picturarum, que foi o primeiro trabalho teórico sobre a representação de santos com base no decreto do concílio de Trento.

Teólogos flamengos como Molnaus e Jodocus Clichtoveus referem-se a uma tradição na iconografia da santa húngara que é representada na maioria, se não exclusivamente por pintores flamengos nos séculos 15-16. Santa Isabel de Hungria é representada com três coroas e, por outro lado, Santa Isabel de Portugal com o famoso milagre das rosas.

Este trabalho tende a analisar a forma como esta tradição aparece num contexto húngaro, além disso, destaca a fase, como no século 17 Santa Isabel de Portugal é adicionado à comunhão dos santos húngaros.

Keywords: $15-17$. centuries, history of civilisation, Hungarian saints, representation of saints, hagiography 